\title{
Intracerebral lymphoproliferative disorder in an MS patient treated with fingolimod
}

Brigit A. de Jong, MD, PhD, Zoé L.E. van Kempen, MD, Mike P. Wattjes, MD, Patrick M. Smit, MD, PhD, Laura Peferoen, MD, PhD, Daniella Berry, MSc, Martine E.D. Chamuleau, MD, PhD, and Daphne de Jong, MD, PhD Neurol Neuroimmunol Neuroinflamm 2018;5:e483. doi:10.1212/NXI.0000000000000483

Fingolimod, an oral sphingosine 1-phosphate (S1P) receptor modulator, is an effective oral immune therapy for treatment of relapsing-remitting MS (RRMS). ${ }^{1}$ Development of solid malignancies was observed in large randomized phase- 3 trials examining the efficacy and safety of fingolimod in patients with RRMS. ${ }^{1}$ In this article, we present a patient who developed a primary central nervous system $\mathrm{T}$-cell lymphoproliferative disorder during fingolimod treatment.

\section{Case report}

In January 2017, a 38-year-old man diagnosed with RRMS 3 years before presented with progressive dysarthria, vertigo, vomiting, and deficits in balance 6 months after starting fingolimod therapy. Fingolimod was initiated because of persistent disease activity after treatment with dimethyl fumarate (2014-2015) and interferon-beta 1a (2015-2016). The patient had no significant medical history other than MS. Neurologic examination showed profound dysarthria and mild left-sided ataxia; with a normal gait. Fingolimod-induced peripheral blood lymphopenia $\left(0.24 \times 10^{9} / \mathrm{L}\right)$ was noted. MRI scan of the brain revealed new multifocal contrastenhancing lesions (figure, A) suggestive of CNS lymphoma. Fingolimod was discontinued immediately. There were no signs of systemic or ocular lymphoma involvement based on history, physical examination, and whole-body PET-CT. Six days after the MRI scan, a stereotactic biopsy of a left cerebellar lesion was performed and dexamethasone $8 \mathrm{mg}$ daily was administered. Three weeks later, MRI scan of the brain revealed a decrease in the size of lesions observed in the previous scan; however, a new contrast-enhancing lesion was observed in the left frontal lobe. Shrinkage of the cerebellar lesion enabled lumbar puncture, which was contraindicated before because of compression on the fourth ventricle. Cerebrospinal fluid showed elevated protein levels $(1.02 \mathrm{~g} / \mathrm{L})$ and leukocyte count $\left(10 \times 10^{6} / \mathrm{L}\right)$ without morphological or immunophenotypical abnormalities. Dexamethasone was tapered and stopped. A second follow-up MRI showed progression of left cerebellar and frontal lesions. A second stereotactic brain biopsy was performed because the first biopsy was considered inconclusive at that time. Both biopsy samples showed a lymphoproliferative process in the normal-appearing brain parenchyma, predominantly $\mathrm{T}$ cells with a small subpopulation of small B cells (figure, B; figure e-1, links.lww.com/NXI/A58). Immunohistochemical and molecular analysis supported oligoclonal proliferation of both $\mathrm{B}$ and $\mathrm{T}$ cells. However, the aberrant T-cell phenotype (CD4 ${ }^{+}$/ $\mathrm{PD}^{+}$) and genotype were most consistent with a reflection of dominant T-cell dysregulation, possibly with premalignant features and likely an association with a minor dysregulated B-cell proliferation (small cell, EBV negative). A diagnosis of overt malignant lymphoma was not appropriate based on these features. Considering the clinical context, a working diagnosis of T-cell primary CNS lymphoma (PCNSL) was made, despite the absence of confirmed T-cell monoclonality. Treatment with 2 induction chemotherapy cycles of MBVP (methotrexate,
Correspondence

Dr. B.A. de Jong

b.dejong@vumc.nl 
Figure Brain MRI findings before and during appearance of lymphoproliferative disorder and pathology findings of cerebellar lesion
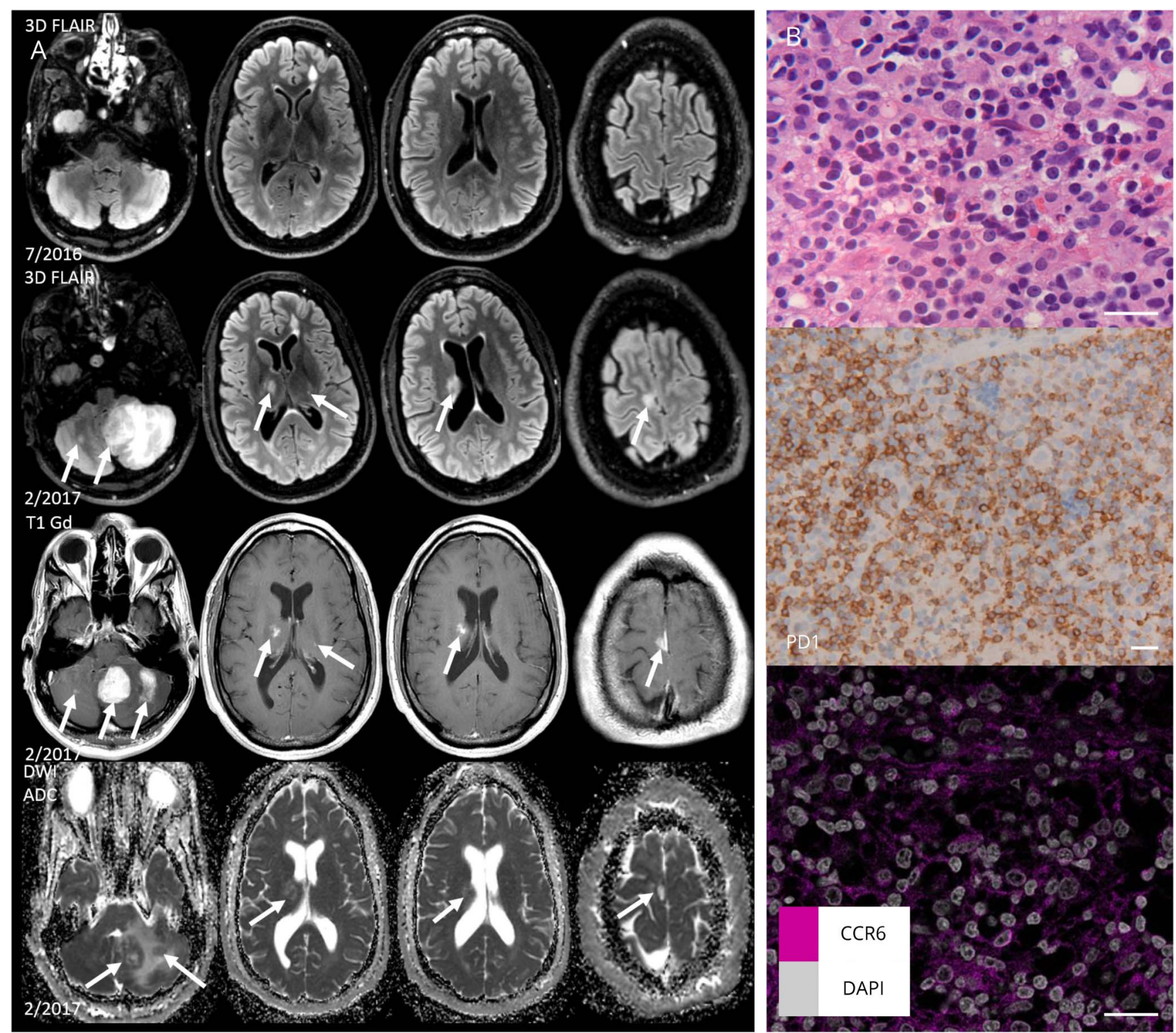

(A) 3D dimensional FLAIR in the axial plane at the time just before fingolimod initiation (July 2016) and after the patient became symptomatic (February 2017). Multifocal new lesions bilateral in the posterior fossa, thalamus, caudate nucleus, and frontal cortical gray matter occurred (arrows). In particular, the lesions in the left cerebellar hemisphere showed mass effect and vasogenic edema. Homogeneous contrast-enhancement patterns on the contrastenhanced T1-weighed images (T1 Gd) and the intermediate low apparent diffusion coefficient (ADC) values of the diffusion weighted (DWI) images suggesting a higher cellularity raised the suspicion of a multifocal lymphoid proliferation. (B) Brain biopsy showing features of a moderately dense smal cell lymphoid infiltrate without cellular atypia and without necrosis. Immunohistochemical staining underpinned a T-cell phenotype (CD3, CD4, CD5, and CD2) with a remarkable large proportion of PD1 positive T cells. There were only few small B cells (CD20, CD79a, and PAX5) and large, transformed cells were lacking. CD3- and CD20-positive cells are shown in figure e-1 (links.Iww.com/NXI/A58). Sporadic EBER-positive small cells were present. Molecular Tcell receptor gene rearrangement analysis showed a pattern consistent with several synchronous dominant clones that differed between the 2 biopsies. This pattern further supported an oligoclonal process. Immunoglobulin gene rearrangement also showed a pattern consistent with an oligoclonal B-cell proliferation. The T-cell phenotype and genotype were most consistent with a reflection of a dominant T-cell dysregulation, possibly with premalignant features and likely in association with a dysregulated B-cell proliferation, which was also of the nontransformed type and EBV negative. Immunohistochemical staining for CCR6 in the lymphoid infiltrate brain tissue was performed according to standard methods (see data supplement, links.Iww.com/ NXI/A59). After washing, nuclear counterstaining was performed using DAPI. ADC = apparent diffusion coefficient; DAPI = 4',6-diamidino-2-phenylindole; $\mathrm{DWI}=$ diffusion weighted images; EBER = in situ hybridization for Epstein-Barr virus; FLAIR = fluid-attenuated inversion recovery; 11 Gd = contrastenhanced T1-weighted. Scale bars $50 \mu \mathrm{m}$.

carmustine, teniposide, and prednisone) resulted in a significant shrinkage of the tumor-like lesions on repeated brain MRI. A subsequent single course of high-dose cytarabine resulted in further remission of the multifocal intracranial process. Consolidation treatment consisted of a conditioning regimen containing carmustine and thiotepa, followed by autologous hematopoietic stem cell transplantation. During treatment and 6 months of followup, MS remained clinically and radiologically stable and the tumor-like lesions shrunk. 


\section{Discussion}

Immunosuppressive or immunomodulating treatments are known to be associated with an increased risk for lymphoproliferative disorders, including PCNSL. Recently, a few case reports reported on the development of a lymphoproliferative disorder in the context of fingolimod treatment, i.e., primary cutaneous $\mathrm{CD} 30^{+} \mathrm{T}$-cell lymphoma, ${ }^{2}$ conjunctival mucosa-associated B-cell lymphoma, ${ }^{3} \mathrm{EBV}+$ diffuse large B-cell lymphoma, ${ }^{4}$ and a B-cell lymphoproliferative disorder restricted to the CNS. ${ }^{5}$ No CNS T-cell lymphoproliferative disorders have been described in association with fingolimod.

At this point, the precise mechanism leading to deregulated infiltration of $\mathrm{T}$ cells, and especially $\mathrm{CD} 4^{+} / \mathrm{PD}^{+} \mathrm{T}$-cells, in our patient is not clear. Therefore, the association with fingolimod treatment should be largely based on the development during treatment. Data indicate that the mode of action of fingolimod is determined by separating autoreactive $\mathrm{T}$ cells in the lymph nodes and raise the activity and numbers of circulating regulatory $\mathrm{T}$ cells. ${ }^{6}$ Especially $\mathrm{CD} 4^{+}$ TH17 T-cell migratory functions may be impaired. At the tissue level in the brain, however, a CCR6-mediated mechanism has shown to overcome this process, resulting in retained influx of an inflammatory $\mathrm{T}$-cell response in the CNS. ${ }^{7}$ This is of relevance because in our patient, the deregulated, oligoclonal populations were primarily of the $\mathrm{PD} 1^{+}$type, a cell population that is known to express CCR6. Indeed, we showed that the atypical infiltrate of our patient was partly positive for CCR6 (figure).

With the increasing use of novel immunomodulatory agents with largely undefined modes of action, prescribing neurologists should be alert to potential rare immunologic and neoplastic complications in association with fingolimod therapy.

\section{Author contributions}

B.A. de Jong and Z.L.E. van Kempen cared for the patient, analyzed the data, and wrote the article. M.P. Wattjes analyzed the data, contributed to MRI imaging, and revised the article for intellectual content. D. de Jong and L Peferoen analyzed the data, contributed to the histopathologic analysis, and revised the article for intellectual content. P.M. Smit and M.E.D.
Chamuleau cared for the patient, analyzed the data, and revised the article for intellectual content.

\section{Acknowledgment}

The authors thank May H. Han for her critical reading of the article.

\section{Study funding}

No targeted funding.

\section{Disclosures}

B.A. de Jong received speaker and consulting fees from Merck-Serono, Biogen, TEVA, Genzyme, and Novartis; Z.L.E. van Kempen reports no disclosures; M.P. Wattjes served on the scientific advisory board for Biogen and Roche and received travel funding and/or speaker honoraria from Biogen, Novartis, Genzyme, and Roche, served on the editorial board for European Radiology, Neuroradiology, and Journal of Neuroimaging, consulted for Biogen, Roche, and IXICO and received speaking fees from Biogen, Novartis, Sanofi-Genzyme, Roche, Merck-Serono, and Celgene; P.M. Smit, L. Peferoen and D. Berry report no disclosures; M. Chanuleau served on the editorial board for Netherlands Journal Hematology, received research support from Gilead, Celgene, Genmab, BMS, and Dutch Cancer Society; D. de Jong served as an associate editor for Histopathology. Full disclosure form information provided by the authors is available with the full text of this article at Neurology.org/NN.

Received December 7, 2017. Accepted in final form June 5, 2018.

\section{References}

1. La Mantia L, Tramacere I, Firwana B, Pacchetti I, Palumbo R, Filippini G. Fingolimod for relapsing-remitting multiple sclerosis. Cochrane Database Syst Rev 2016;4: CD009371.

2. Papathemeli D, Grafe R, Hildebrandt U, Zettl UK, Ulrich J. Development of a primary cutaneous $\mathrm{CD} 30(+)$ anaplastic large-cell T-cell lymphoma during treatment of multiple sclerosis with fingolimod. Mult Scler 2016;22:1888-1890.

3. Christopher KL, Elner VM, Demirci H. Conjunctival lymphoma in a patient on fingolimod for relapsing-remitting multiple sclerosis. Ophthalmic Plast Reconstr Surg 2017;33:e73-e75.

4. Kira J, Itoyama Y, Kikuchi S, et al. Fingolimod (FTY720) therapy in Japanese patients with relapsing multiple sclerosis over 12 months: results of a phase 2 observational extension. BMC Neurol 2014;14:21.

5. Baharnoori M, Mahajan R, Solomon IH, Pinkus G, Houtchens M. Fingolimodassociated intracerebral lymphoproliferative disorder. Am J Ther Epub 2017 Oct 27.

6. Pelletier D, Hafler DA. Fingolimod for multiple sclerosis. N Engl J Med 2012;366: 339-347.

7. Tsai HC, Huang Y, Garris CS, Moreno MA, Griffin CW, Han MH. Effects of sphingosine-1-phosphate receptor 1 phosphorylation in response to FTY720 during neuroinflammation. JCI Insight 2016;1:e86462. 


\section{Neurology \\ Neuroimmunology \& Neuroinflammation}

Intracerebral lymphoproliferative disorder in an MS patient treated with fingolimod Brigit A. de Jong, Zoé L.E. van Kempen, Mike P. Wattjes, et al.

Neurol Neuroimmunol Neuroinflamm 2018;5;

DOI 10.1212/NXI.0000000000000483

This information is current as of July 10, 2018

\section{Updated Information \& Services}

References

Citations

Subspecialty Collections

Permissions \& Licensing

Reprints including high resolution figures, can be found at:

http://nn.neurology.org/content/5/5/e483.full.html

This article cites 5 articles, 0 of which you can access for free at: http://nn.neurology.org/content/5/5/e483.full.html\#\#ref-list-1

This article has been cited by 3 HighWire-hosted articles: http://nn.neurology.org/content/5/5/e483.full.html\#\#otherarticles

This article, along with others on similar topics, appears in the following collection(s):

All Demyelinating disease (CNS)

http://nn.neurology.org//cgi/collection/all_demyelinating_disease_cns Multiple sclerosis

http://nn.neurology.org//cgi/collection/multiple_sclerosis

Information about reproducing this article in parts (figures,tables) or in its entirety can be found online at:

http://nn.neurology.org/misc/about.xhtml\#permissions

Information about ordering reprints can be found online:

http://nn.neurology.org/misc/addir.xhtml\#reprintsus

Neurol Neuroimmunol Neuroinflamm is an official journal of the American Academy of Neurology.

Published since April 2014, it is an open-access, online-only, continuous publication journal. Copyright

Copyright (C) 2018 The Author(s). Published by Wolters Kluwer Health, Inc. on behalf of the American

Academy of Neurology.. All rights reserved. Online ISSN: 2332-7812.



